\title{
Grizzly Bear and Human Interaction in Yellowstone National Park: An Evaluation of Bear Management Areas
}

\section{Authors: Tyler H. Coleman, Charles C. Schwartz, Kerry A. Gunther, and Scott Creel}

This is the peer reviewed version of the following article: Coleman, TH, Schwartz, CC, Gunther, KA, Creel, S. 2013. Grizzly bear and human interaction in Yellowstone National Park: An evaluation of bear management areas. Journal of Wildlife Management 77: 1311-1320, which has been published in final form at http://dx.doi.org/10.1002/jwmg.602. This article may be used for non-commercial purposes in accordance with Wiley Terms and Conditions for Self-Archiving.

Coleman, TH, Schwartz, CC, Gunther, KA, Creel, S. 2013. Grizzly bear and human interaction in Yellowstone National Park: An evaluation of bear management areas. Journal of Wildlife Management 77: 1311-1320.

Made available through Montana State University's ScholarWorks scholarworks. montana.edu 


\title{
Grizzly Bear and Human Interaction in Yellowstone National Park: An Evaluation of Bear Management Areas
}

\author{
Tyler H. Coleman, ${ }^{1,2}$ Department of Ecology, Montana State University, Bozeman, MT 59717, USA; and Yellowstone National Park, \\ Bear Management, Yellowstone Center for Resources, Mammoth, WY 82190, USA \\ Charles C. Schwartz, C Schwartz Consulting, Bozeman, MT 59178, USA \\ Kerry A. Gunther, Yellowstone National Park, Bear Management, Yellowstone Center for Resources, Mammoth, WY 82190, USA \\ Scott Creel, Department of Ecology, Montana State University, Bozeman, MT 59717, USA
}

\begin{abstract}
Wildlife managers often rely on permanent or temporary area closures to reduce the impact of human presence on sensitive species. In 1982, Yellowstone National Park created a program to protect threatened grizzly bears (Ursus arctos) from human disturbance. The bear management area (BMA) program created areas of the park where human access was restricted. The program was designed to allow unhindered foraging opportunities for bears, decrease the risk of habituation, and provide safety for backcountry users. The objective of our study was to evaluate human-bear interaction in BMAs and determine if they were effective. We used human and grizzly bear global positioning system location data to study 6 of 16 BMAs from 2007 to 2009. We contrasted data when BMAs were unrestricted (open human access) and restricted (limited human access). We used location data collected when BMAs were unrestricted to delineate a human recreation area (HRA) and determined a daily human active and inactive period. We applied the HRA and daily activity times to bear location data and evaluated how bear movement behavior changed when people were present and absent. We found that grizzly bears were twice as likely to be within the HRA when BMAs were restricted. We also found that grizzly bears were more than twice as likely to be within the HRA when BMAs were unrestricted, but people were inactive. Our results suggest that human presence can displace grizzly bears if people are allowed unrestricted access to the 6 BMAs in our study. Our study provides evidence for the utility of management closures designed to protect a threatened species in a well-visited park. Our approach can be reapplied by managers interested in balancing wildlife conservation and human recreation.
\end{abstract}

Mitigating human disturbance of sensitive, threatened, or endangered species in protected areas is important because they serve as core areas for species recovery and provide a baseline for research (Sinclair and Byrom 2006). Concerns arise when places suitable for wildlife conservation are also popular with people. Human presence can alter wildlife behavior and ultimately change foraging patterns (Steidl and Anthony 2000, Rode et al. 2007), modify intra- and interspecific interactions (Mattson et al. 1987, Skagen et al. 1991, Rogala et al. 2011), increase physiological stress (Creel et al. 2002, Barja et al. 2007), reduce survival (Ruhlen et al. 2003), decrease reproductive output (Ellenberg et al. 2007), and lead to habituation (Herrero et al. 2005). Also, some wildlife species can be defensive over food, personal space, or mates, placing people at risk. Therefore, land managers use various methods to minimize potential human disturbance and reduce human-wildlife overlap (Leung and Marion 1999). One commonly used method is to close or restrict human access to allow foraging, nesting, or breeding behavior (Ashe et al. 2010, Burger and Niles 2012). However, this approach can constrain human recreation or exclude people from popular places and activities. Therefore, considerations must be made when closing or restricting human access. Managers must understand the consequences of human-wildlife interaction and determine if management closures provide adequate protection for animals and people (Whittaker and Knight 1998, Ferna'ndez-Juricic et al. 2004, Ashe et al. 2010). They must also determine if specific areas, times, and dates are effectively reducing potential interactions. These considerations allow managers to understand the consequences of inaction and help refine protocols to reduce unnecessary regulation.

Management closures involving moose (Alces alces; National Park Service 2013), grizzly bears (Ursus arctos; Parks Canada 2013), killer whales (Orcinus orca; Williams 
et al. 2006), shorebirds (Burger and Niles 2012), and various other species (Thurstan et al. 2012) are used to reduce human impact or protect humans. Yellowstone National Park (YNP) also uses management closures to protect threatened grizzly bears. Bear management areas (BMAs) were created in the 1982 YNP Grizzly Bear Management Environmental Impact Statement (National Park Service 1982). Mostly designed for the backcountry, BMAs seasonally restrict recreation in areas of YNP with high seasonal concentrations of grizzly bears and bear foods. Sixteen BMAs were created in 1982 and are still in place. BMAs comprise 188,032 ha (21\%) of YNP and have unique management guidelines (Gunther 2003). Program goals include 1) minimizing human-bear interactions that may lead to habituation, 2) preventing human-caused displacement of bears from prime food sources, and 3) decreasing the risk of bear-caused human injury in areas with high levels of bear activity (National Park Service 1982). The program goals are still relevant to park management; however, in 1982 habituation was considered to have primarily negative consequences. Recent research indicates that habituation has benefits and risks to bears and people (Aumiller and Matt 1994, Herrero et al. 2005, Smith et al. 2005).

BMAs can be used to research the effectiveness of management closures for several reasons. They have been in place for $>30$ years, cover a large area, are strictly enforced, exist in a highly visited place, and have coincided with an increase in grizzly bear population (Schwartz et al. 2006). Evaluating an established program can provide a template for new management closures or provide recommendations for existing programs.

Few attempts have been made to assess the efficacy of YNP's BMA program or quantify the consequence of human-grizzly bear interaction in the YNP backcountry. Gunther (1990) found that seasonal closures and time of day hiking restrictions were effective at limiting human-bear interaction and maintaining the $3 \mathrm{BMA}$ goals. Outside of YNP, studies of recreation and grizzly bears have often focused on a single resource or commonly used area, such as a spawning stream (Jope 1985, Smith 2002, Tollefson et al. 2005, Rode et al. 2007). Other studies have focused solely on the impact of consumptive use or motorized recreation (Mace et al. 1996, Graves 2002, Podruzny et al. 2002, Johnson et al. 2005, Ordiz et al. 2012). Some research has been limited by very high frequency radio collars, which provide an approximate location and restrict times or dates of data collection (Hebblewhite and Haydon 2010, Urbano et al. 2010). Research using global positioning system (GPS) technology to evaluate the influence of non-consumptive recreation on a threatened bear population has been lacking in a backcountry setting.

As part of a comprehensive study of the behavior and diet of grizzly bears in YNP, we had the opportunity to evaluate human-bear interaction in 6 selected BMAs. We used GPS location data of bears and people to assess the influence of backcountry recreation on bear movement behavior. One aspect of our study was to determine the location and likelihood of potential human-bear interactions in BMAs if regulations were not in place and people were allowed to recreate freely. Because of safety concerns, we were unable to allow access to the 6 BMAs during restricted dates. Therefore, we collected human recreation data while BMAs were unrestricted and applied what we learned to the same BMAs during the restricted time periods.

When BMAs were annually unrestricted, we examined 1) the bi-weekly distance of grizzly bears from areas of human use, 2) the odds of grizzly bear occupancy in areas of human use, and 3) the odds of grizzly bear occupancy in areas of human use when people were less active. We applied the same methods when BMAs were restricted to contrast bear movement behavior and understand the amount and consequence of potential human-bear interaction. Our objective was to evaluate the effectiveness of BMAs and provide considerations for researchers using or developing other management closures.

\section{STUDY AREA}

We conducted our study in the southeast portion of YNP from April 2007 to October 2009. Yellowstone National Park lies in the core of the Greater Yellowstone Ecosystem (GYE), which is geographically defined as the Yellowstone Plateau and the surrounding mountain ranges above 1,500$3,600 \mathrm{~m}$. Grizzly bears use habitats within this range throughout the GYE (Schwartz et al. 2002). The main geographic and recreational characteristic of the study area is Yellowstone Lake. Yellowstone Lake is a high elevation $(2,359 \mathrm{~m})$ oligotrophic lake that covers 35,391 ha with a mean depth of $42 \mathrm{~m}$. The east and southeast drainage of Yellowstone Lake is dominated by larger stream tributaries draining from high mountain topography, closed canopy mixed forest, and subalpine meadows. The west and north drainages are characterized by smaller streams draining from low relief plateau topography, lodgepole pine (Pinus contorta) forest, and alluvial meadows. The 10-year (1998-2008) mean high and low temperatures were $-5.4^{\circ} \mathrm{C}$ and $-17.0^{\circ} \mathrm{C}$, respectively, in January and $23.3^{\circ} \mathrm{C}$ and $4.6^{\circ} \mathrm{C}$, respectively, in July at Yellowstone Lake (Western Regional Climate Center 2010). Approximately, 80\% of precipitation typically falls as snow (Reinhart and Mattson 1990, Fortin et al. 2013).

Patterns of precipitation and temperature produce predictable vegetation patterns (Marston and Anderson 1991). Douglas-fir (Pseudotsuga menziesii) forms the lowestelevation forest community at 1,900-2,200 m. Lodgepole pine ( $P$. contorta) dominates mid-elevations where poor soils formed from rhyolite $(2,400 \mathrm{~m})$. With increasing elevation, spruce-fir or subalpine forests dominate. Engelmann spruce (Picea engelmannii) and whitebark pine (P. albicaulis) form the upper tree line (2,600-2,900 m). Alpine tundra occurs at the highest reaches of all major mountain ranges (Patten 1963, Waddington and Wright 1974, Despain 1990, Schwartz et al. 2002).

\section{Bear Management Areas and Human Recreation}

Our study area consisted of 6 of 16 BMAs: Clear Creek \#1, Clear Creek \#2, Lake Spawn, Riddle Lake, Two Ocean 
Plateau, and Heart Lake. All 6 BMAs were near or adjacent to Yellowstone Lake and comprised 81,176 ha or $9.0 \%$ of the park. Elevation ranged from the shoreline of Yellowstone Lake to the top of Two Ocean Plateau at 3,062 m. The 6 BMAs were $97.3 \%$ recommended wilderness, which prohibited motorized equipment and any type of road building. The study area was accessible by man-powered watercraft, foot, equine stock, and motorboats in limited circumstances. Other forms of transportation or recreation were prohibited.

Access for recreational users was via foot and equine stock trailheads or from $177 \mathrm{~km}$ of Yellowstone Lake shoreline. Yellowstone Lake provided access for backcountry trips via boat drops, personal watercraft, or hiking from designated backcountry campsites on the shoreline. Four major trailheads led into and through the 6 BMAs (Riddle Lake, Ninemile, Heart Lake, and South Boundary trailheads). These trailheads allowed foot and equine stock travel on $160 \mathrm{~km}$ of maintained trail and permitted day or overnight use. All day users could access the 6 BMAs without informing YNP, whereas overnight users were required to obtain a permit and reserve backcountry campsites. The 6 BMAs contained 54 designated backcountry campsites (14 accessible by boat only, 12 accessible by boat, foot, or equine stock, and 28 accessible by foot or equine stock only).

The 6 study area BMAs were created by YNP because, prior to 1982, the area had a relatively high density of grizzly bears (National Park Service 1982, Gunther 2003). Grizzly bear densities were thought to be high because of seasonal foods, such as spawning Yellowstone cutthroat trout (Oncorbynchus clarki), winter-killed elk (Cervus elaphus) and bison (Bison bison) carcasses, elk calves, whitebark pine nuts, and lush vegetation associated with the Yellowstone Lake tributaries, shoreline, and thermal areas (National Park Service 1982). The 6 BMA restrictions differed slightly but, in general, human use was largely restricted before 1 July and mostly unrestricted thereafter. From early spring to 1 July, human recreation was limited to a subset of backcountry campsites, off-trail travel was restricted, and several trail segments were closed. A mean of $4.5 \pm 9.4(\bar{x} \pm \mathrm{SD})$ recreational users per day were in the 6 BMAs during this time period (2007-2009). Following 1 July, the 6 BMAs showed a sharp increase in human use. July, August, and September reflected the peak of seasonal recreation. The increase was the result of improved weather, lake fishing starting 15 June, permitted equine stock use starting 1 July, and employee entrance for trail and patrol cabin maintenance. By 15 July, all 6 BMAs were open and unrestricted. From 1 July to 30 September, the 6 BMAs had a mean of $146.7 \pm 61.2$ recreational users per day. By 1 October, human use dropped off substantially because of inclement weather and the closure of park facilities. During October, a mean of $10.9 \pm 12.1$ recreational users were in the BMA per day (Fig. 1).

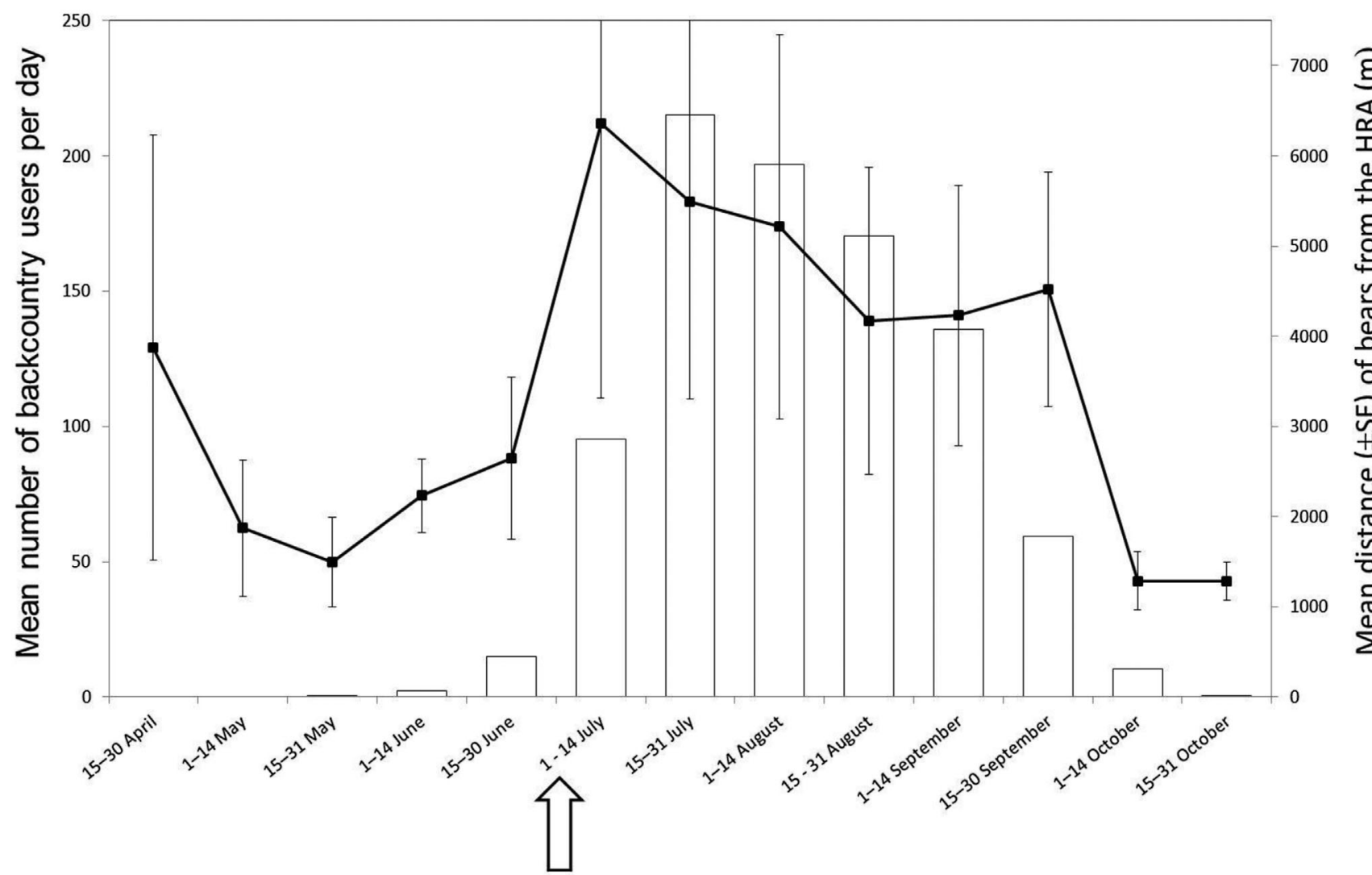

BMA restrictions lifted

Figure 1. Mean number of backcountry users per day (bars) and mean weighted distance $( \pm \mathrm{SE})$ of grizzly bears from the human recreation area (HRA; line) by date. The study area comprised the 6 bear management areas (BMA) south and east of Yellowstone Lake, Yellowstone National Park, between 2007 and 2009. 


\section{METHODS}

We trapped and radio collared grizzly bears between fall 2006 and summer 2009. The Interagency Grizzly Bear Study Team conducted all trapping under procedures approved by the Animal Care and Use Committee of the United States Geological Survey, Biological Resources Division and conformed to the Animal Welfare Act and United States Government principles for the use and care of vertebrate animals used in testing, research, and training. The team used culvert traps placed within $1 \mathrm{~km}$ of Yellowstone Lake to capture grizzly bears that used the 6 BMAs. The team fitted all captured bears with Telonics Spread Spectrum GPS collars (Telonics, Inc., Mesa, AZ) with a biodegradable canvas spacer and a CR2-A programmable remote drop-off device set for a specific release date. Collars obtained a position fix every 30 or 60 minutes and shut off during the denning season (15 Nov to 14 Apr). We flew telemetry flights weekly from late April through mid-October to retrieve collar data. We calculated fix success and excluded collars that malfunctioned because of antenna fatigue. Bears that immediately dispersed after capture and did not frequent the BMAs were not included in the sample or considered for analysis.

We sampled overnight backcountry recreational users and day users during July, August, and September from 1 July 2007 to 30 September 2009. We met sampled parties at trailheads and boat access points. We asked 1 member of each party to carry a Garmin $12 \mathrm{XL}$ or Garmin e-Trex GPS on their trip (Garmin International, Inc., Olathe, KS). Survey procedures conformed to Montana State University's Institutional Review Board, Human Subjects Committee guidelines. We asked individuals to leave the GPS unit on while hiking so as to record all movements except when boating. We programmed GPS units to obtain a fix at 1 location/minute for trips $\leq 2$ days, and 1 location/ 2 minutes for trips $>2$ days. We based our sample of overnight users using data from the YNP backcountry permit system. We applied a stratified random sample design with proportional allocation among 4 strata: private users, outfitters, park employees or research groups staying in designated backcountry campsites, and park employees or research groups staying in backcountry cabins. The sampling frame for overnight users was a list of any recreational party that reserved at least 1 designated backcountry campsite that required travel through 1 of the $6 \mathrm{BMAs}$, including any park employee or researcher. We attempted to sample approximately $20 \%$ of users from each strata per week. Day users were not required to obtain a backcountry permit; therefore, we sampled day users by randomly selecting 1 of 2 study area trailheads frequently used by day users (Nine Mile and Riddle Lake trailheads). We sampled day users 1 day/week during July, August, and September from 1 July 2007 to 30 September 2009. We stationed a crew member at the selected trailhead from 0700-1800 hours on sample days and selected every other hiking group. We asked recreational parties to return GPS units to park staff upon completion of their trip. We used Garmin Map Source 4.0 (Garmin Inc.) to download all GPS units to a computer. The GPS units provided a universal transverse mercator (UTM) location, date, and time for each fix. If a GPS unit failed to obtain a satellite connection or did not log data at the 1-2-minute rate, we removed those days from analysis. We recorded the number of individuals and recreation type (equine stock or foot) for each party. We considered any party that accessed the BMAs by boat would travel by foot when off the water and any party with equine stock would always travel on horseback.

To determine an area consistently used by people we delineated a human recreation area (HRA) within the BMAs. We separated all human GPS locations into 2 groups: on-trail and off-trail users. We defined off-trail use as any hike that was $>100 \mathrm{~m}$ beyond a maintained backcountry trail for $>15$ minutes. We considered all other hikes to be on-trail. We defined a hike as a continuous walking or horse riding path with no intentional break in GPS locations. To create the HRA, we first divided the backcountry trail system into $1-\mathrm{km}$ segments. We calculated the total number of sampled on-trail hikers per segment. We created a distribution of these segments and deleted those with the fewest hikers (the fewest 10\%). We deleted some segments because we wanted the HRA to reflect areas of consistent use and did not want to include spur trails and short cuts with little human presence. Second, we divided all off-trail hikes into $1-\mathrm{km}$ segments and calculated the distance to the nearest maintained trail or backcountry camp for each segment. We created a distribution of these segments and deleted those that were farthest from any maintained trail or campsite (the farthest 10\%). We deleted these off-trail segments because they often involved lone hiking groups in extremely remote locations (i.e., mountain peaks) and did not reflect consistent human use. We assigned a buffer to all GPS locations within the remaining on-trail and off-trail hiking segments; buffers were equal to the mean distance a backcountry user traveled per minute, plus 1 standard deviation, plus $10 \mathrm{~m}$ to incorporate GPS error (Wing et al. 2005). All backcountry campsites received the same buffer. This formula provided space to incorporate erratic movements for a hiking or horse party between successive GPS locations. We merged the buffers to create the HRA layer.

To assess available cover for bears, we determined the percent of forested, non-forested, and mixed area cover types within the HRA using a digitized version of the Despain (1990) cover type classification. To calculate mean elevation for the HRA, we generated 1,000 random locations and associated elevations within the HRA boundaries. We used ArcGIS 9.3 (Environmental System Research Institute, Inc., Redlands, CA) to produce the HRA layer and delineate cover type areas. We used the Alaska Pak toolkit (National Park Service, Alaska Pak v2.2 for ArcGIS 9.x, http://science. nature.nps.gov/im/gis/alaskapak.cfm, accessed 13 Aug 2009) in ArcGIS 9.3 to generate random locations.

To establish times of the day when people were actively recreating in the HRA, we used the time associated with each GPS location. We pooled all GPS location times from all years and calculated the percent of hikers actively moving 
(away from a campsite or trailhead) at sequential 15-minute intervals for a 24-hour period. We determined a cutoff for the human active period when $10 \%$ of all sampled parties were active in the morning and $90 \%$ of parties were inactive in the evening (i.e., they were done hiking or at a campsite).

\section{Bear and Human Interaction Analysis}

To evaluate bear movement behavior in relation to human presence or absence, we considered 2 distinct annual time periods for the BMAs. We defined a BMA restricted period as 15 April (den emergence) to 30 June and a BMA unrestricted period as 1 July to 30 September. We excluded October and November because inclement weather limited recreation and collars were designed to drop off on 1 October.

A key assumption was that humans would recreate in a similar manner if allowed access during the BMA restricted period. We made this assumption because many of the areas people used during the unrestricted period would be accessible in the restricted period, including the trails and campsites that served as starting points for off-trail travel. (I. Kowski, YNP Central Backcountry Office, personal communication). During the BMA restricted period, use was allowed in limited circumstances and we were able to sample 4 recreational parties. The parties recorded 8 hikes in 8 days. All GPS locations were within the HRA boundaries and all hiking occurred within the human active period. Consequently, we felt the HRA and daily activity times could be applied to the BMA restricted period.

We used the distance of bears from the HRA to describe seasonal bear movement behavior in relation to annual trends in backcountry recreation. We measured the distance of each bear GPS location to the HRA at 2-week periods from 15 April to 31 October. We used the regression approach of Murtaugh (2007) and fit no-intercept models to distance. Resulting coefficient estimates were sample mean distances and standard errors for each bear. We summarized the results for all bears in each 2-week period using the weighted average of the bear-specific regression coefficients, with weights proportional to reciprocals of the squared standard errors for individual fits (Murtaugh 2007, Schwartz et al. 2010).

We used the HRA to determine if bears selected areas of human use more or less than random and if a change occurred when BMAs were restricted or unrestricted. We compared bear locations to random locations within each animal's home range. We created individual home ranges using the $k$ nearest neighbor convex hull method $(k-\mathrm{LoCoH})$ with $k=(\sqrt{n} / 2)$ (Getz and Wilmers 2004, Getz et al. 2007). We used the $k$ - LoCoH method because it delineated the shoreline of Yellowstone Lake, where a lot of recreation occurred. We created the home range shapefiles using the LoCoH home range generator for ArcGIS 9.x (University of California, LoCoH home range generator for ArcGIS 9, http://nature.berkeley.edu/ ajlyons/locoh, accessed $21 \mathrm{Apr}$ 2011). We chose $100 \%$ isopleths as a boundary for random locations. We generated an equal number of random locations to GPS locations per bear. We used the Alaska
Pak Toolkit in ArcGIS 9.3 to generate random locations. We enumerated the bear locations and random locations within and outside the HRA. We created $2 \times 2 \times K$ contingency tables with $K=$ individual bear, to control for individual bear effects. To quantify the amount of human overlap and potential human influence, we analyzed data when BMAs were unrestricted and restricted.

We also investigated the spatial and temporal patterns of human recreation to assess potential influence on bear movement behavior. We used the HRA layer and human active and inactive periods to assess bear locations in relation to human presence and daily activity. We categorized bear locations into 6 ordinal bins (within the HRA, 0-100 m from the HRA boundary, $>100-200 \mathrm{~m},>200-300 \mathrm{~m}$, $>300-400 \mathrm{~m}$, and $>400-500 \mathrm{~m}$ ). We enumerated bear locations within and outside each ordinal bin during the human active and inactive periods. We created $2 \times 2 \times K$ contingency tables with $K=$ individual bear. To evaluate the influence of human presence, we analyzed data when BMAs were unrestricted and restricted.

For both analyses, we used an exact inference procedure to estimate odds ratios in the 3-way contingency tables (bear or random location, within or outside the HRA, individual bear) and (human active or inactive period, within or outside the HRA/distance bin, individual bear). We conditioned the test on fixed-strata marginal totals and used an exact smallsample alternative to the Cochran-Mantel-Haenzel (CMH) test (Agresti 2007:114). Our null hypothesis was that the odds ratios were $=1$ (equal odds). We accepted the alternative hypothesis for any odds ratio where the 95\% confidence interval did not overlap 1. A key $\mathrm{CMH}$ test assumption was that individual bears shared a common odds ratio. We evaluated this by fitting log-linear models corresponding to this assumption and plotting fitted values with observed values. The plots allowed for a visual assessment of the reasonability of the common odds ratio assumption (Haroldson et al. 2004). We conducted our analysis using the statistical program $\mathrm{R}$ ( $\mathrm{R}$ version 2.12.2, www.r-project.org, accessed 2 Sep 2011).

\section{RESULTS}

We deployed 18 radio collars on 14 bears including 10 male and 4 female bears. Our GPS collars successfully obtained $84.3 \%$ of 72,443 fix attempts. We sampled 385 recreational parties, including 286 overnight parties from the 4-sample strata and 99 day parties from selected trailheads. In our sample, 345 parties traveled by foot (trailhead or boat access) and 40 traveled on horseback. Our sample totaled 1,341 people with a mean of $447 \pm 59.2$ people/year $(\bar{x} \pm \mathrm{SD})$. Mean party size was $3.48 \pm 2.87(\bar{x} \pm \mathrm{SD})$, with a median and mode of 2 and range of $1-15$. Within the 6 BMAs, the sampled parties recorded 827 usable foot hikes and 140 horse rides. On-trail use was common with hikers including 554 (67.0\%) staying on-trail the entire time, $220(26.6 \%)$ going off and on-trail during the same hike, and 53 (6.4\%) going completely off-trail for the entire hike. All horseback riders traveled on-trail. Recreational parties collected 205,004 GPS 
locations available for analysis. We did not use 3,604 GPS locations for analysis because of inadequate data acquisition, including 17 hikes from 15 parties.

The buffer around each GPS location and backcountry campsite was $102 \mathrm{~m}(66+26.3+10),(\bar{x}+\mathrm{SD}+10 \mathrm{~m}$ GPS error). The HRA was $6,251.4$ ha or $7.7 \%$ of the 6 BMAs. The HRA was a near continuous polygon because many GPS locations overlapped. The HRA polygon was $74.7 \%$ forested cover, $18.1 \%$ non-forested cover, and $7.2 \%$ mix of non-forested and forested cover. The mean elevation for the HRA was $2,426.2 \pm 140.8 \mathrm{~m}(\bar{x} \pm \mathrm{SD})$. Within the HRA, we determined that $>10 \%$ of people were actively recreating after 0800 hours and $>90 \%$ of people were no longer recreating after 1900 hours. Therefore, the human active period was $0800-1859$ hours and the inactive period was 1900-0759 hours (Fig. 2).

\section{Bear Distances From Human Recreation Area}

When the BMAs were restricted, the weighted mean distances and standard errors of bears from the HRA were $3,875 \pm 2,357 \mathrm{~m}$ from 15 to 30 April, $1,874 \pm 757 \mathrm{~m}$ from 1 to 14 May, $1,498 \pm 404 \mathrm{~m}$ from 15 to 31 May, $2,233 \pm 404 \mathrm{~m}$ from 1 to 14 June, and 2,651 $\pm 901 \mathrm{~m}$ from 15 to 30 June (Fig. 1). When the BMAs were unrestricted bears were further away from the HRA with weighted mean distances and standard errors of $6,364 \pm 3,050 \mathrm{~m}$ from 1 to 14 July, 5,498 $\pm 2,190 \mathrm{~m}$ from 15 to 31 July, 5,216 $\pm 2,132 \mathrm{~m}$ from 1 to 14 August, $4,174 \pm 1,704 \mathrm{~m}$ from 15 to 31 August, 4,229 $\pm 1,443 \mathrm{~m}$ from 1 to 14 September, and 4,519 $\pm 1,302 \mathrm{~m}$ from 15 to 30 September. During October, bears were closer to the HRA with weighted mean distances and standard errors of $1,288 \pm 324 \mathrm{~m}$ from 1 to 14 October and 1,283 $\pm 209 \mathrm{~m}$ from 15 to 31 October.

\section{BMA Restricted Period (Den Emergence to 30 June)}

During the restricted period, grizzly bears locations were more likely to be within the HRA (10.1\%), compared to random locations (5.5\%). The odds of bear locations being within the HRA during the restricted period were 2 times more likely $(95 \% \mathrm{CI}=1.81-2.14, P \leq 0.001)$ than random (Fig. 2A). A visual comparison of the plots between fitted values from log-linear models and observed values suggested the common odds ratio assumption was met in all odds ratios.

During the restricted period, $9.4 \%$ of bear locations were within the HRA during the human active period and $10.8 \%$ during the inactive period (Fig. 2A). However, the odds were near equal and were consistent at $100-\mathrm{m}$ intervals away from the HRA. This suggests that bears showed no time of day preference when people were absent from the study area. The $95 \%$ confidence intervals for the odds ratios overlapped 1 at 100-200 m, 300-400 m, and 400-500 m (Fig. 3). The odds of a bear being within the HRA while humans were projected to be inactive was 1.18 times greater than when people were projected to be active $(95 \% \mathrm{CI}=1.06-1.31$, $P=0.002)$. The odds at $0-100 \mathrm{~m}$ were 1.17 times greater $(95 \% \mathrm{CI}=1.01-1.36, P=0.035)$. The odds at $100-200 \mathrm{~m}$ did not significantly differ from 1 and were 1.14 times greater (95\% CI $=0.98-1.33, P=0.098)$. The odds at $200-300 \mathrm{~m}$ were 1.18 times greater $(95 \% \mathrm{CI}=1.00-1.39, P=0.045)$. The odds at $300-400 \mathrm{~m}$ and $400-500 \mathrm{~m}$ did not statistically differ from 1 at $1.14(95 \% \mathrm{CI}=0.96-1.36, P=0.132)$ and 0.96 times greater $(95 \% \mathrm{CI}=0.83-1.14, \quad P=0.585)$, respectively.

\section{BMA Unrestricted Period (1 July to 30 September)}

During the unrestricted period, grizzly bear locations were more likely to be within the HRA (6.9\%), compared to random locations (5.2\%). The odds of bear locations being within the HRA were 1.35 times more likely (95\% $\mathrm{CI}=1.27-1.44, P \leq 0.001$ ) than random (Fig. 2B).

During the unrestricted period, $4.4 \%$ of bear locations were within the HRA during the human active period and 9.1\% during the inactive period (Fig. 2B). The odds of a bear being located within the HRA during the human inactive period was 2.15 times greater than the active period $(95 \%$ $\mathrm{CI}=1.96-2.37, P \leq 0.001)$. However, at 100 - $\mathrm{m}$ intervals
A Bear Management Area restricted

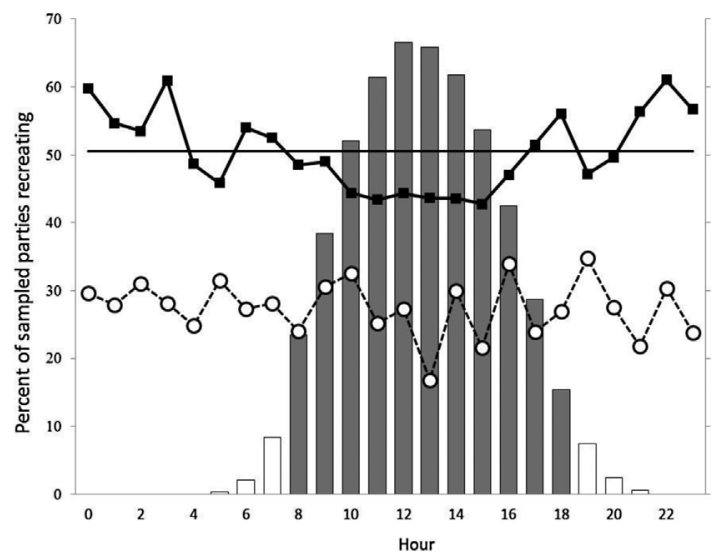

B Bear Management Area unrestricted

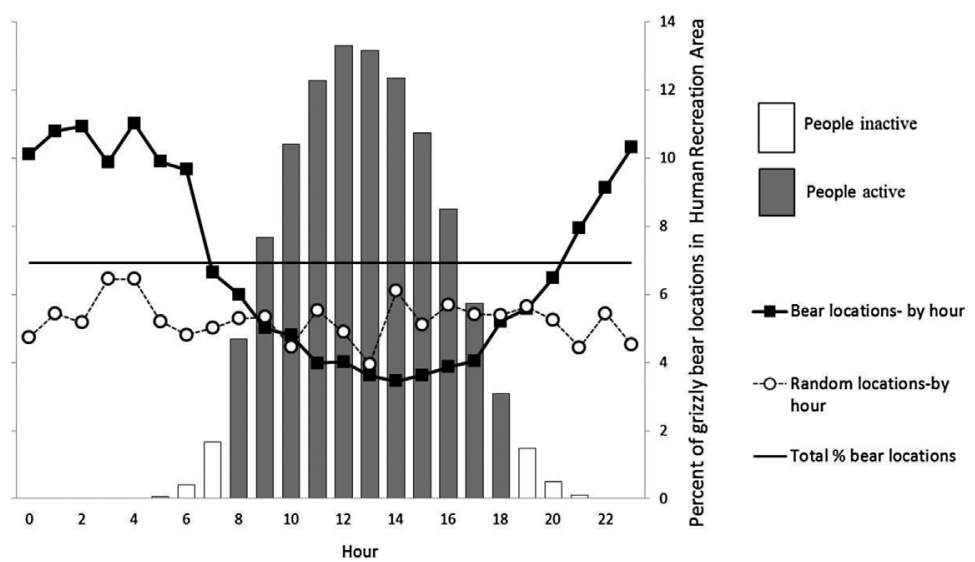

Figure 2. Percent of grizzly bear and random locations within the human recreation area (lines), compared to times when people were active (bars). Dates cover the bear management area (BMA) restricted (A) and unrestricted (B) periods. The study area comprised the 6 BMAs south and east of Yellowstone Lake, Yellowstone National Park, between 2007 and 2009. 


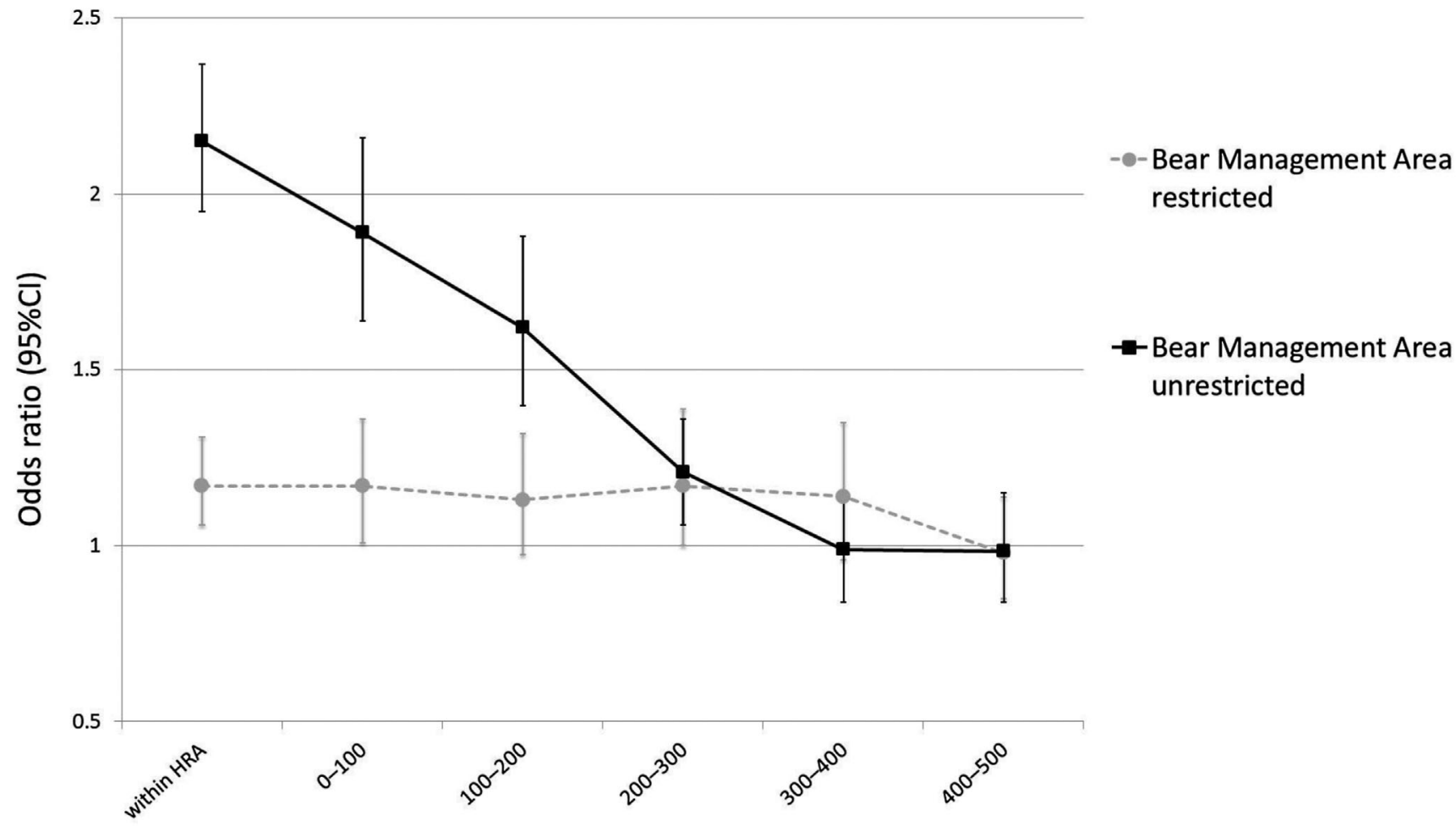

Grizzly bear location distance from Human Recreation Area $(\mathrm{m})$

Figure 3. Odds ratios and $95 \%$ confidence intervals for grizzly bears near the human recreation area (HRA) during bear management area (BMA) restricted and unrestricted periods. The study area comprised the 6 BMAs south and east of Yellowstone Lake, Yellowstone National Park, between 2007 and 2009.

the odds decreased incrementally, suggesting that the presence of people may influence bear movement behavior, but only within a short distance (approx. $300 \mathrm{~m}$ ) of places people frequent. The $95 \%$ confidence intervals for the odds ratios were significantly greater than 1 until $300-400 \mathrm{~m}$ and 400-500 m from the HRA (Fig. 3). The odds of a bear being within $0-100 \mathrm{~m}$ of the HRA during the human inactive period was 1.89 times greater than the active period $(95 \%$ $\mathrm{CI}=1.64-2.17, P \leq 0.001)$. The odds of a bear being within 100-200 m of the HRA during the human inactive period was 1.63 times greater than the active period $(95 \%$ $\mathrm{CI}=1.41-1.89, P \leq 0.001)$. The odds of a bear being within 200-300 m of the HRA during the human inactive period was 1.21 times greater than the active period $(95 \%$ $\mathrm{CI}=1.06-1.37, \quad P=0.004)$. We found no significant difference between the human inactive and active periods at $300-400 \mathrm{~m}$ and $400-500 \mathrm{~m}$ with 0.99 odds (95\% $\mathrm{CI}=0.84-1.15, P=0.847)$ and 0.99 odds $(95 \% \mathrm{CI}=$ $0.84-1.15, P=0.847)$, respectively.

\section{DISCUSSION}

If humans were allowed access to BMAs during the restricted period, our results suggest an increase in human-caused displacement of bears. Seasonal bear distribution patterns showed that bears were closer to the HRA when backcountry human use was reduced and farther away when human use increased (Fig. 1). Bears also showed a stronger attraction to the HRA when BMAs were restricted (Fig. 2). Since this was an observational study, we can only describe an association between human recreation and bear movement behavior. However, other research has detected similar patterns (Gunther 1990, Kasworm and Manley 1990, Mace and Waller 1996, Apps et al. 2006).

The absence or presence of humans in the backcountry may have contributed to bear use and proximity to the HRA, but other explanations exist. Overall park visitation, annual weather conditions, and daily bear activity likely played a role as well. Park visitation is low in spring and early summer, high in mid-summer, and low in autumn (National Park Service 2012). Visitation trends may influence bear movement behavior because they often avoid busy developed areas and occupied recreation trails (Mattson et al. 1987, Kasworm and Manley 1990, Mace and Waller 1996, Graves 2002, Apps et al. 2006). Snowpack may also influence bear movement behavior because it peaks in April, melts by mid-summer, and accumulates in mid-October (Despain 1990). High elevation sites $(>2,600 \mathrm{~m})$ may not provide space or access to bear foods until mid-summer when most recreation occurs. If bears move to higher elevations, they become separated from humans who recreate at relatively lower elevations. Finally, grizzly bears in the GYE are more day active in spring and autumn (Schwartz et al. 2010). Day-active bears may use backcountry trails and other human travel corridors more when the weather is cool and people are absent.

Seasonal foods also played a role in bear movement behavior relative to the HRA. Seasonal foods in our study 
area were addressed in complementary research by Fortin et al. (2013). Other research also describes foods and corresponding elevations in YNP (Mealey 1980, Despain 1990, Reinhart and Mattson 1990, Blanchard and Knight 1991, Mattson et al. 1991). The HRA had a relatively low elevation with a mean of 2,426.2 $\pm 140.8 \mathrm{~m}$ $(\bar{x} \pm \mathrm{SD})$, which is approximate to Yellowstone Lake, the lowest portion of our study area. In the spring and early summer, bears often feed on riparian area vegetation, elk calves, and winter killed ungulates that are associated with lower elevation, snow-free areas. During the mid to late summer, grizzly bears often move to higher elevations, thus farther from the HRA, to access green grasses, forbs, and whitebark pine. Whitebark pine is common at 2,6002,900 m (Patten 1963, Waddington and Wright 1974, Despain 1990). During the autumn, grizzly bears may return to lower elevations closer to the HRA. In September and October, female grizzly bears feed on false-truffles (Rhizopogon spp.) if whitebark pine nuts are limited. False-truffles are found in lodgepole pine forests, which occur at elevations near the HRA (approx. 2,400 m; Fortin et al. 2013). During October, bears also move to lower elevations because of accumulating snow and reduced access to whitebark pine nuts.

Prior to our study, bears foraged on cutthroat trout in the Yellowstone Lake tributaries that bisect the backcountry trail system. However, bear consumption of cutthroat trout has dropped from an estimated 20,900/year in the late 1980s to 302/year in 2007-2009 (Stapp and Hayward 2002, Fortin et al. 2013). Consequently, cutthroat trout were not likely a driver of seasonal bear movement behavior. With the decline in cutthroat trout, no seasonal foods concentrated near the backcountry trail system, backcountry camps, or other areas commonly used by humans. Nevertheless, during the BMA restricted period, bears continued to show a preference for the HRA. Furthermore, if current efforts to restore cutthroat trout are successful, bear occurrence in the HRA will only increase in May, June, and early July (Koel et al. 2012, Teisberg 2012).

An evaluation of bear movement behavior when BMAs were unrestricted helped determine the potential consequences of human-bear interaction. When BMAs were unrestricted, bears continued to show a preference for the HRA, but this preference mostly occurred when people were inactive (Fig. 2). Also, the preference changed incrementally up to $300-400 \mathrm{~m}$ from the HRA, where time of day preference was equivalent. When BMAs were restricted, bears showed consistent use at $100-\mathrm{m}$ intervals from the HRA, regardless of time of day (Fig. 3). This suggests an avoidance response of bears to people. This is noteworthy considering the low human use in our study area. The 6 $\mathrm{BMAs}$ are relatively remote and, despite our intensive sampling design, we only sampled 447 people/year. The HRA was $62.5 \mathrm{~km}^{2}$; thus, during the unrestricted period, we calculated 7 sampled people $/ \mathrm{km}^{2} /$ year within the HRA. We also determined that the most common group size was 2 . These results suggest bears were sensitive to relatively small increases in human use.
Our results are consistent with other research on humanbear interaction in close proximity $(<1 \mathrm{~km}$; McLellan and Shackleton 1989, Gunther 1990, Smith 2002, Sundell et al. 2006, Moen et al. 2012). However, we considered alternative explanations. We considered that bears were avoiding mid-day heat when BMAs were unrestricted and the response was thermally influenced. During our study, July and August were the 2 warmest months in YNP (Western Regional Climate Center 2010). The backcountry trail system traversed large meadows, rolling hills, and areas with uniform terrain. The human off-trail tracks followed ridge lines, thermal areas, and meadows where elevation was consistent or lower at 300-400 m from the HRA. Therefore, temperatures at $300-400 \mathrm{~m}$ were not likely cooler than within the HRA. Also, the 6 BMAs and HRA were densely forested and provided ample cover for day beds. Yellowstone National Park is approximately $80 \%$ forested (Despain 1990) and the HRA was $74.7 \%$ forested and $7.2 \%$ mixed forested or non-forested. We suggest that bears were moving $300-400 \mathrm{~m}$ to avoid the presence of people and not seek cover.

The BMA restrictions reduced bear displacement behavior by limiting potential human-bear interaction. This is beneficial because an avoidance response of bears to people would be energetically costly in May and June. Recently, grizzly bears in our study area have become more dependent on ungulate meat because of the decline in cutthroat trout (Fortin et al. 2013). Winter killed ungulates and elk calves are primarily available in May and June, when BMAs are restricted. During our study, we confirmed 2 circumstances where grizzly bears were displaced from ungulate meat because of proximity to hikers (approx. $120 \mathrm{~m}$; Coleman 2012). Smith (2002) and Rode et al. (2007) also found that human interaction can displace bears from foraging opportunities. If bears are displaced from ungulate meat, they may lose foraging opportunities via inter- or intraspecific competition (Mattson 1997, Gunther and Smith 2004). Other research has found that lost foraging opportunities can be regained at night, when people are absent (Olson et al. 1998, Smith 2002). However, the BMA program was designed to prevent bears from making these type of costly behavioral adjustments. Furthermore, if bears do not abandon meat when interacting with humans, they can be aggressive, increasing the probability of an attack (Herrero 2002).

\section{MANAGEMENT IMPLICATIONS}

Our results provide evidence for the usefulness and applicability of BMAs. Regardless of additional variables, the annual restrictions help reduce overlap and decrease the risk of human-bear interaction. If current BMA rules did not exist, bears would be displaced from prime foraging opportunities as suggested by our findings. The associated loss of foraging opportunities or increased energetic demand may pose a risk to the bear population (Ruxton and Lima 1997, Frid and Dill 2002, Creel et al. 2007, Pangle et al. 2007). Future research can evaluate these questions. 
The methods described can be reapplied to the same BMAs at a later date, used on other BMAs, or applied to other management closures. In other cases, researchers should consider the extent of human-wildlife overlap. We estimated that humans used $7.7 \%$ of the 6 study area BMAs, which allowed us to focus our research and identify specific areas of concern. Researchers should also consider the outcome of human-wildlife interactions. This provides guidelines for setting rules and suitable approach distances. Obtaining finescale human use data provides details on how humans use areas important to conservation and how human presence can alter wildlife movement behavior. It also helps isolate times, areas, and dates of concern. This understanding can ultimately provide greater protection for wildlife and may help eliminate unnecessary restrictions.

\section{ACKNOWLEDGMENTS}

Funding for this project was provided by the National Park Service, National Resource Protection Program (Natural Resource Management Section), Rocky Mountain Cooperative Ecosystem Studies Unit, Greater Yellowstone Coordinating Committee, and Yellowstone Bear Management Office. We thank S. Cherry for project discussions, statistical assistance, and editing early drafts of the manuscript. Personnel support was provided by the Yellowstone Bear Management Office and the United States Geological Survey Interagency Grizzly Bear Study Team. We thank C. Whitman, C. Dickinson, J. Ball, G. Rasmussen, and S. Thompson for their trapping effort and M. O'Reilly, J. Fortin, J. Teisberg, S. Podruzny, and I. Kowski for field assistance.

\section{LITERATURE CITED}

Agresti, A. 2007. An introduction to categorical data analysis. Second edition. John Wiley and Sons, Inc., Hoboken, New Jersey, USA.

Apps, C. D., B. N. McLellan, and J. G. Woods. 2006. Landscape partitioning and spatial inferences of competition between black and grizzly bears. Ecography 29:561-572.

Ashe, E., D. P. Noren, and R. Williams. 2010. Animal behaviour and marine protected areas: incorporating behavioural data into the selection of marine protected areas for an endangered killer whale population. Animal Conservation 13:196-203.

Aumiller, L. D., and C. A. Matt. 1994. Management of McNeil River State Game Sanctuary for viewing of brown bears. International Conference on Bear Research and Management 9:51-61.

Barja, I., G. Silvan, S. Rosellini, A. Pineiro, A. Gonzalez-Gil, L. Camacho, and J. C. Illera. 2007. Stress physiological responses to tourist pressure in a wild population of European pine marten. Journal of Steroid Biochemistry and Molecular Biology 104:136-142.

Blanchard, B. M., and R. R. Knight. 1991. Movements of Yellowstone grizzly bears. Biological Conservation 58:41-67.

Burger, J., and L. Niles. 2012. Shorebirds and stakeholders: effects of beach closure and human activities on shorebirds at a New Jersey coastal beach. Urban Ecosystems. <http://link.springer.com/article/10.1007/s11252012-0269-9>. Accessed 14 Dec 2012.

Coleman, T. H. 2012. Grizzly bear and human interaction in Yellowstone National Park, bear management areas. Dissertation, Montana State University, Bozeman, USA.

Creel, S., J. E. Fox, A. Hardy, J. Sands, B. Garrott, and R. O. Peterson. 2002. Snowmowbile activity and glucocorticoid stress responses in wolves and elk. Conservation Biology 16:809-814.

Creel, S., D. Christianson, S. Liley, and J. A. Winnie. 2007. Predation risk affects reproductive physiology and demography of elk. Science 315:960.
Despain, D. G. 1990. Yellowstone vegetation: consequences of environment and history in a natural setting. Roberts Rinehart Publishing Company, Boulder, Colorado, USA.

Ellenberg, U., A. N. Setiawan, A. Cree, D. M. Houston, and P. J. Seddon. 2007. Elevation hormonal stress response and reduce reproductive output in yellow-eyed penguins exposed to unregulated tourism. General and Comparative Endocrinology 152:54-63.

Fernández-Juricic, E., R. Vaca, and N. Schroeder. 2004. Spatial and temporal responses of forest birds to human approaches in a protected area and implications for two management strategies. Biological Conservation 117:407-416.

Fortin, J. K., C. C. Schwartz, K. A. Gunther, J. E. Teisberg, M. A. Haroldson, M. A. Evans, and C. T. Robbins. 2013. Dietary adjustability of grizzly bears and American black bears in Yellowstone National Park. Journal of Wildlife Management 77:270-281.

Frid, A., and L. Dill. 2002. Human-caused disturbance stimuli as a form of predation risk. Conservation Ecology 6:11. < http://www.consecol.org/ vol6/iss1/art11/>. Accessed 2 Sep 2011.

Getz, W. M., and C. C. Wilmers, 2004. A local nearest-neighbor convexhull construction of home ranges and utilization distributions. Ecography 4:489-505.

Getz, W. M., S. Fortmann-Roe, P. C. Cross, A. J. Lyons, S. J. Ryan, and C. C. Wilmers. 2007. LoCoH: nonparameteric kernel methods for constructing home ranges and utilization distributions. PLoS ONE 2: e207.

Graves, T. A. 2002. Spatial and temporal response of grizzly bears to recreational use on trails. Thesis, University of Montana, Missoula, USA.

Gunther, K. A. 1990. Visitor impact on grizzly bear activity in Pelican Valley, Yellowstone National Park. International Conference on Bear Research and Management 8:73-78.

Gunther, K. A. 2003. Yellowstone National Park bear management area program, YELL. 705. Information paper BMO-5. Yellowstone National Park, Bear Management, Office, Wyoming, USA.

Gunther, K. A., and D. W. Smith. 2004. Interactions between wolves and female grizzly bears with cubs in Yellowstone National Park. Ursus $15: 232-238$

Haroldson, M. A., C. C. Schwartz, S. Cherry, and D. Moody. 2004. Possible effects of elk harvest on fall distribution of grizzly bears in the greater Yellowstone ecosystem. Journal of Wildlife Management 68:129137.

Hebblewhite, M., and D. T. Haydon. 2010. Distinguishing technology from biology: a critical review of the use of GPS telemetry data in ecology. Philosophical transactions of the Royal Society of London, Series B, Biological Sciences 365:2303-2312.

Herrero, S. 2002. Bear attacks: their causes and avoidance. Revised edition. Lyons Press, Guilford, Connecticut, USA.

Herrero, S., T. Smith, T. D. Debruyn, K. Gunther, and C. A. Matt. 2005. From the field: brown bear habituation to people-safety, risks, and benefits. Wildlife Society Bulletin 33:362-373.

Johnson, C. J., M. S. Boyce, R. L. Case, H. D. Cluff, R. J. Gau, and R. Mulders. 2005. Cumulative effects of human developments on arctic wildlife. Wildlife Monographs 1-36.

Jope, K. L. 1985. Implications of grizzly bear habituation to hikers. Wildlife Society Bulletin 13:32-37.

Kasworm, W. F., and T. L. Manley. 1990. Road and trail influences on grizzly bears and black bears in northwest Montana. International Conference on Bear Research and Management 8:79-84.

Koel, T. M., J. L. Arnold, P. E. Bigelow, P. D. Doepke, B. D. Ertel, and M. E. Ruhl. 2012. Yellowstone fisheries \& aquatic sciences: annual report, 2011. National Park Service, Yellowstone Center for Resources, Yellowstone National Park, Wyoming, USA.

Leung, Y., and J. L. Marion. 1999. Spatial strategies for managing visitor impacts in national parks. Journal of Park and Recreation Administration 17:20-38.

Mace, R. D., and J. S. Waller. 1996. Grizzly bear distribution and human conflicts in Jewel Basin hiking area, Swan Mountains, Montana. Wildlife Society Bulletin 24:461-467.

Mace, R. D., J. S. Waller, T. L. Manley, L. J. Lyon, and H. Zuuring. 1996. Relationships among grizzly bears, roads and habitat in the Swan Mountains, Montana. Journal of Applied Ecology 33:13951404.

Marston, R. A., and J. E. Anderson. 1991. Watersheds and vegetation of the Greater Yellowstone Ecosystem. Conservation Biology 5:338-346. 
Mattson, D. J. 1997. Use of ungulates by Yellowstone grizzly bears. Biological Conservation 81:161-177.

Mattson, D. J., R. R. Knight, and B. M. Blanchard. 1987. The effects of developments and primary roads on grizzly bear habitat use in Yellowstone. International Conference on Bear Research and Management 7:259-273.

Mattson, D. J., B. M. Blanchard, and R. R. Knight. 1991. Food habits of Yellowstone grizzly bears, 1977-1987. Canadian Journal of Zoology 69:1619-1629.

McLellan, B. N., and D. M. Shackleton. 1989. Immediate reactions of grizzly bears to human activities. Wildlife Society Bulletin 17:269-274.

Mealey, S. P. 1980. The natural food habits of grizzly bears in Yellowstone National Park, 1973-74. International Conference on Bear Research and Management 3:281-292.

Moen, G. K., O.-G. Støen, V. Sahlén, and J. E. Swenson. 2012. Behaviour of solitary adult Scandinavian brown bears (Ursus arctos) when approached by humans on foot. PLoS ONE 7:e31699.

Murtaugh, P. A. 2007. Simplicity and complexity in ecological data analysis. Ecology 88:56-62.

National Park Service. 1982. Final environmental impact statement, grizzly bear management program. U.S. Department of the Interior, Yellowstone National Park, Wyoming, USA.

National Park Service. 2012. National Park Service Public Use Statistics Office. Summary report (multiple years), YELL visitation by month/year. $<$ http://www.nature.nps.gov/stats/park.cfm>. Accessed 22 Jan 2012.

National Park Service. 2013. Denali National Park, wildlife closures. $<$ http://www.nps.gov/dena/naturescience/wildlifeclosures.htm $>$. Accessed 15 Jan 2013

Olson, T. L., R. C. Squibb, and B. K. Gilbert. 1998. Brown bear diurnal activity and human use: a comparison of two salmon streams. Ursus 10:547-555.

Ordiz, A., O. G. Støen, S. Sxbø, J. Kindberg, M. Delibes, and J. E. Swenson. 2012. Do bears know they are being hunted? Biological Conservation 152:21-28.

Pangle, K. L., S. D. Peacor, and O. E. Johannsson. 2007. Large nonlethal effects of an invasive invertebrate predator on zooplankton population growth rate. Ecology 88:402-412.

Parks Canada. 2013. Banff National Park, seasonal closures and restrictions. $<$ http://www.pc.gc.ca/pn-np/ab/banff/visit/fermetures-closures.aspx $>$. Accessed 15 Jan 2013.

Patten, D. T. 1963. Vegetational pattern in relation to environments in the Madison Range, Montana. Ecological Monographs 33:375-406.

Podruzny, S. R., S. Cherry, C. C. Schwartz, and L. A. Landenburger. 2002. Grizzly bear denning potential conflict areas in the Greater Yellowstone Ecosystem. Ursus 13:19-28.

Reinhart, D. P., and D. J. Mattson. 1990. Bear use of cutthroat trout spawning streams in Yellowstone National Park. International Conference on Bear Research and Management 8:343-350.

Rode, K. D., S. D. Farley, J. Fortin, and C. T. Robbins. 2007. Nutritional consequences of experimentally introduced tourism in brown bears. Journal of Wildlife Management 71:929-939.

Rogala, J. K., M. Hebblewhite, J. Whittington, C. A. White, J. Coleshill, and M. Musiani. 2011. Human activity differentially redistributes large mammals in the Canadian Rockies National Park. Ecology and Society 16:16. <http://www.ecologyandsociety.org/vol16/iss3/art16/>. Accessed 14 Dec 2012.

Ruhlen, T. D., S. Abbott, L. E. Stenzel, and G. W. Page. 2003. Evidence that human disturbance reduces snowy plover chick survival. Journal of Field Ornithology 74:300-304.
Ruxton, G. D., and S. L. Lima. 1997. Predator-induced breeding suppression and its consequences for predator-prey population dynamics. Proceedings of the Royal Society B 264:409-415.

Schwartz, C. C., M. A. Haroldson, K. A. Gunther, and D. Moody. 2002. Distribution of grizzly bears in the Greater Yellowstone Ecosystem, 19902000. Ursus 13:203-212.

Schwartz, C. C., M. A. Haroldson, G. C. White, R. B. Harris, S. Cherry, K. A. Keating, D. Moody, and C. Servheen. 2006. Temporal, spatial, and environmental influences on the demographics of grizzly bears in the Greater Yellowstone Ecosystem. Wildlife Monographs 161:1-68.

Schwartz, C. C., S. L. Cain, S. Podruzny, S. Cherry, and L. Frattaroli. 2010. Contrasting activity patterns of sympatric and allopatric black and grizzly bears. Journal of Wildlife Management 74:1628-1638.

Sinclair, A. R. E., and A. E. Byrom. 2006. Understanding ecosystem dynamics for conservation of biota. Journal of Animal Ecology 75:64-79.

Skagen, S. K., R. L. Knight, and G. H. Orians. 1991. Human disturbance of an avian scavenging guild. Ecological Applications 1:215-225.

Smith, T. S. 2002. Effects of human activity on brown bear use of the Kulik River, Alaska. Ursus 13:257-267.

Smith, T. S., S. Herrero, and T. D. DeBruyn. 2005. Alaskan brown bears, humans, and habituation. Ursus 16:1-10.

Stapp, P., and G. Hayward. 2002. Estimates of predator consumption of Yellowstone cutthroat trout in Yellowstone Lake. Journal of Freshwater Ecology 17:319-329.

Steidl, R. J., and R. G. Anthony. 2000. Experimental effects of human activity on breeding bald eagles. Ecological Applications 10:258-268.

Sundell, J., I. Kohola, and I. Hanski. 2006. A new GPS-GSM-based method to study behavior of brown bears. Wildlife Society Bulletin $34: 446-450$

Teisberg, J. E. 2012. Applied investigations into grizzly bear (Ursus arctos) and black (U. americanus) bear ecology and management. Dissertation, Washington State University, Pullman, USA.

Thurstan, R. H., J. P. Hawkins, L. Neves, and C. M. Roberts. 2012. Are marine reserves and non-consumptive activities compatible? A global analysis of marine reserve regulations. Marine Policy 36:1096-1104.

Tollefson, T. N., C. Matt, J. Meehan, and C. T. Robbins. 2005. Quantifying spatiotemporal overlap of Alaskan brown bears and people. Journal of Wildlife Management 69:810-817.

Urbano, F., F. Cagnacci, C. Calenge, H. Dettki, A. Cameron, and M. Neteler. 2010. Wildlife tracking data management: a new vision. Philosophical Transactions of the Royal Society of London, Series B, Biological Sciences 365:2177-2185.

Waddington, J. C. B., and H. E. Wright. Jr. 1974. Late Quaternary vegetational changes on the east side of Yellowstone Park, Wyoming. Quaternary Research 4:175-184.

Western Regional Climate Center. 2010. Historical climate information. $<$ http://www.wrcc.dri.edu $>$. Accessed 22 Dec 2010.

Whittaker, D., and R. L. Knight. 1998. Understanding wildlife responses to humans. Wildlife Society Bulletin 26:312-317.

Williams, R., D. Lusseau, and P. S. Hammond. 2006. Estimating relative energetic costs of human disturbance to killer whales (Orcinus orca). Biological Conservation 133:301-311.

Wing, M. G., A. Eklund, and L. D. Kellogg. 2005. Consumer-grade global positioning system (GPS) accuracy and reliability. Journal of Forestry 103:169-173.

Associate Editor: Scott McCorquodale. 